\title{
Working
}

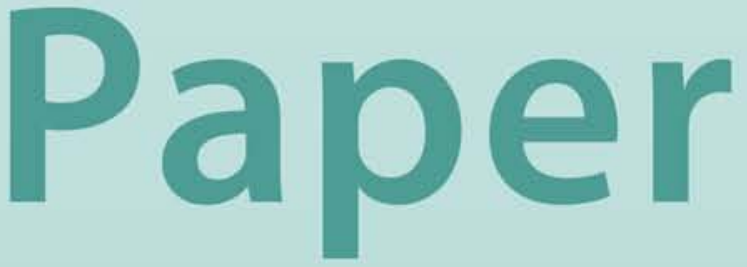




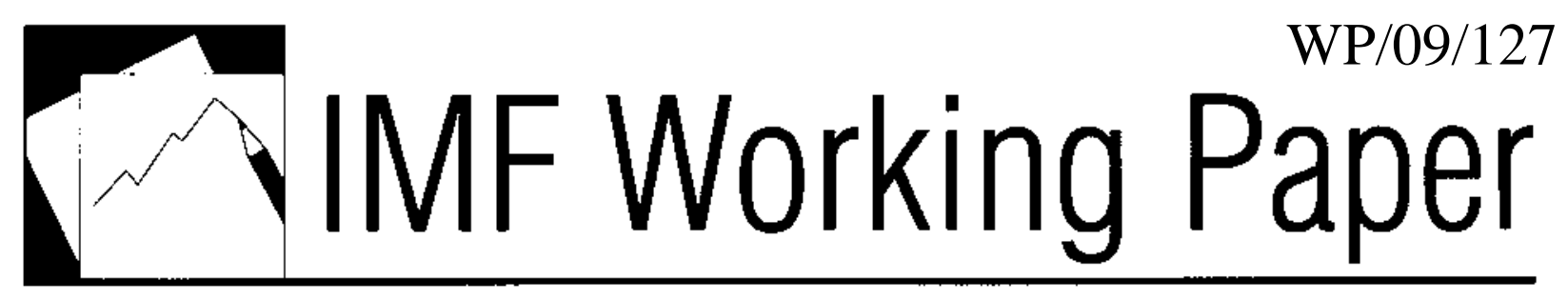

Current Accounts in a Currency Union

Jörg Decressin and Emil Stavrev 


\title{
IMF Working Paper
}

Research Department and European Department

\section{Current Accounts in a Currency Union}

\section{Prepared by Jörg Decressin and Emil Stavrev ${ }^{1}$}

June 2009

\begin{abstract}

\section{This Working Paper should not be reported as representing the views of the IMF.} The views expressed in this Working Paper are those of the author(s) and do not necessarily represent those of the IMF or IMF policy. Working Papers describe research in progress by the author(s) and are published to elicit comments and to further debate.

A fear about EMU was that in the absence of national currencies, country-specific shocks would result in greater current account divergences between member states. This paper finds that divergences across euro-area countries are smaller and have not risen relative to those across 13 other advanced economies with more flexible exchange rates. Also, the size of country-specific current account shocks in EMU countries is smaller and their persistence is greater than in the other advanced economies. However, these differences in current account dynamics do not appear related to different exchange rate dynamics.
\end{abstract}

JEL Classification Numbers:F31, F32, F33

Keywords: current account, currency union, EMU, real exchange rate

Author’s E-Mail Address: jdecressin@imf.org; estavrev@imf.org

\footnotetext{
${ }^{1}$ We would like to thank Menzie Chinn, Charles Collyns, Hamid Faruqee, Antonio Fatás, Jaewoo Lee, GianMaria Milesi-Ferretti, David Romer, Marco Terrones, and participants in ECB and IMF seminar series for helpful comments and suggestions, as well as Mandy Hemmati and Emory Oakes for excellent research assistance. All remaining errors are our own.
} 
I. Introduction .........................................................................................................

II. The Literature ............................................................................................................

III. The Data.............................................................................................................

IV. Current Account Divergences and Dynamics.....................................................................

V. The Role of the Exchange Rate and Other Factors ................................................................

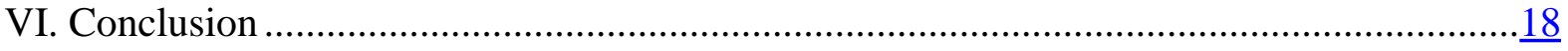

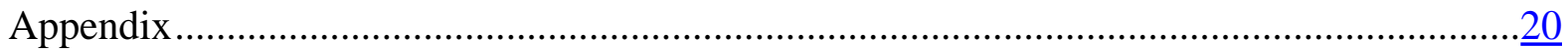

Tables

Table 1. Estimates of Speed of Adjustment of Current Accounts .............................................. 10

Table 2. Current Account and Real Exchange Rate Persistence ...............................................14

Table 3. Estimates of the Current Account Equation …………………………………….......

Table 4. EMU Countries: Current Account Dispersions and NFA ……………………….......

Figures

Figure 1. Current Account Dispersions ....................................................................................

Figure 2. Adjustment to Country-Specific Current Account Shocks 1/ ...................................

Figure 3. Real Exchange Rate Dispersions...........................................................................

Figure 4a: EMU and Other Countries: Impulse Responses of the Current Account ................12

Figure 4b: EMU and Other Countries: Impulse Responses of the Real Exchange Rate ...........13

Figure 5. EMU and Other Countries: Correlation Between Current Account...........................14

Figure 6. EMU Countries: Fundamental Current Account Dispersions ....................................17

Figure 7. EMU Countries: Dispersions of Determinants of Current Accounts ..........................18

Figure 8: EMU Countries: Testing for Structural Breaks ........................................................20

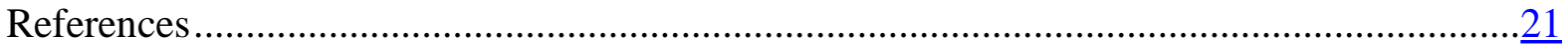




\section{INTRODUCTION}

European Economic and Monetary Union (EMU) makes for an interesting case study of current account developments and their relation with currency regimes. An important fear about EMU was that in the absence of national currencies, country-specific shocks would result in larger and more persistent current account imbalances between member states that would severely undermine the functioning of monetary union (e.g., Feldstein, 1997).

Some 10 years after the introduction of the euro on January 1, 1999, the purpose of this paper is to see whether these fears have been realized. Accordingly, the paper proposes to investigate cross-country current account divergences and dynamics in 11 EMU countries and compare the findings with those for a sample of 13 other advanced countries with more flexible exchange rates.

The findings are nuanced with respect to current account divergences and speed of adjustment to shocks but generally do not point to the real exchange rate as a decisive factor. Current account divergences across euro-area countries have risen since the early 1990s, i.e., well before the onset of monetary union and the cross-country dispersion of real exchange rate changes has fallen. However, current account divergences have also risen across the other advanced economies, while the dispersion of their real exchange rate changes has remained broadly unchanged. Also, both before and after monetary union intra euro-area divergences have typically been smaller than those across the other advanced economies. Unlike in the other advanced economies, the size of current account shocks in EMU members has become smaller, consistent with increasing economic integration, although adjustment to these shocks has slowed significantly. These changes occurred mainly before the advent of monetary union and they are robust to conditioning on real exchange rate dynamics. Thus, prima facie, they do not appear related to high intra-area exchange rate

rigidity. Simple cross-sectional evidence suggests that current account and real exchange rate persistence do not appear significantly related across the 24 countries. Accordingly, other determinants of current accounts are likely to explain the slower adjustment to shocks in the euro area.

The remainder of the paper is structured as follows: Section II reviews the relevant literature; Section III discusses the data; Section IV studies cross-sectional current account developments for EMU countries and a sample of 13 other advanced economies as well as current account shocks and dynamics; Section V investigates the relation between exchange rate and current account dispersions and dynamics and looks at the behavior of some fundamental determinants of current accounts; and Section VI concludes.

\section{THE LITERATURE}

The debate on the role of exchange rate regimes for current account dynamics is ongoing. Friedman (1953) argued that exchange rate volatility is a symptom not a cause of external 
imbalances and therefore fixing the exchange rate only masks the problems without solving them. Chinn and Wei (2008) dispute the importance of exchange rate regimes in current account persistence. They find no strong, robust, or monotonic relationship between exchange rate regime flexibility and current account persistence, even after controlling for the degree of economic development and the level of trade and capital account openness. However, Ghosh and others (2008) conclude that Friedman's original hypothesis does enjoy much empirical support when controlling for the size of the current account deficits. They find empirical evidence that large current account imbalances are rare under flexible currency regimes, and when they do occur, the initial imbalances are lower than under intermediate and fixed exchange rate regimes.

The analysis of current account dispersions and the role of the exchange rate regime shifts under EMU does not feature prominently in the literature. European Commission (2006) reviews adjustment to divergences and argues that wage and price rigidities influence the efficiency of the adjustment process and could lead to protracted current account and other economic divergences. Their key finding is that over the medium term the adjustment process in the euro area is dynamically stable, because changes in competitiveness dominate following country-specific shocks. However, this channel can operate slowly, and it is not exempt from some overshooting. Schmitz and von Hagen (2009) find that the elasticity of current account balances with respect to per capita income has increased within the euro area but not between euro-area countries and the rest of the world. They interpret this as evidence suggesting that the introduction of the euro has lead to some financial diversion. Faruqee and Lee (2008) study current account divergences at the global level: using a panel of more than hundred countries they find that the global dispersion of current accounts has been increasing steadily. They conclude that this is qualitatively consistent with the ongoing financial globalization, which has allowed countries to maintain larger current account imbalances.

Economic dispersions in the euro area have been analyzed extensively from the viewpoint of output and inflation. Eickmeir (2006), Giannone and Reichlin (2006) and Stavrev (2007), for example, find that growth and inflation of EMU members are driven by a large and rising common component, while dispersions are due to country-specific shocks and are comparable to those among the US states. ${ }^{2}$ However, the propagation of shocks is more persistent in the euro area than in the United States. Furthermore, Stavrev (2007) finds that among the remaining idiosyncratic factors are income and price level convergence among EMU countries, the forces of which can be expected to gradually diminish over time.

\footnotetext{
${ }^{2}$ For a broad overview and references, see also ECB (2008).
} 


\section{THE DATA}

The country samples include: (i) 11 euro area members: Austria, Belgium, Finland, France, Germany, Greece, Ireland, Italy, Netherlands, Portugal, and Spain, and, (ii) 13 other advanced countries: Australia, Canada, Denmark, Iceland, Israel, Japan, Korea, New Zealand, Norway, Sweden, Switzerland, United Kingdom, and United States. ${ }^{3}$

The data are taken from the Spring 2008 IMF World Economic Outlook (WEO), World Bank World Development Indicators (WDI), and IMF International Financial Statistics (IFS) databases. All data are at annual frequency and cover countries' current accounts (in percent of GDP), real GDP growth, net foreign assets (in percent of GDP), fiscal balance (in percent of GDP), the oil balance (in percent of GDP), and exchange rates. In addition to the above variables, the old age dependency ratio and the population growth rate from the WDI are used as proxies for demographics.

\section{Current Account Divergences ANd Dynamics}

This section discusses cross-sectional current account divergences among EMU countries as well as among 13 other advanced economies. Additionally, it studies country-specific current account shocks and dynamics.

\section{Cross-sectional current account divergences}

A simple approach to gauge divergences is to compute cross-sectional standard deviations of current accounts for the two samples, the 11 EMU countries and the 13 other advanced economies, respectively. The key finding is that intra euro-area divergences have grown since the early 1990s, i.e., well before the onset of monetary union. However, they are presently not far out of line with previous historical peaks. Furthermore, they have fallen relative to divergences across the 13 other advanced economies.

The divergences for both samples have lately been on the rise, but to a larger degree for the other advanced countries than for the euro-area countries (Figure 1). In fact, unlike in the euro area, divergences in the other advanced economies lately reached proportions that are far higher than at any time since 1980. The ratio of the two sample standard deviations checks whether current account divergences within the euro area are unusually wide relative to those in the sample of the other advanced economies. The mean and median values of this ratio are, respectively, 0.85 and 0.75 . As can be seen, the ratio has not grown over time. This result is in line with findings in other studies. For example, Faruqee and Lee (2008) show

\footnotetext{
${ }^{3}$ This is the full sample of advanced countries outside the current euro area, according to the IMF's World Economic Outlook classification of countries. Notice that Luxembourg and Singapore, which are also advanced economy countries under the IMF's World Economic Outlook classification, are not considered because of their unusual degree of openness and status as financial centers.
} 
Figure 1. Current Account Dispersions

(Standard deviation of current accounts)

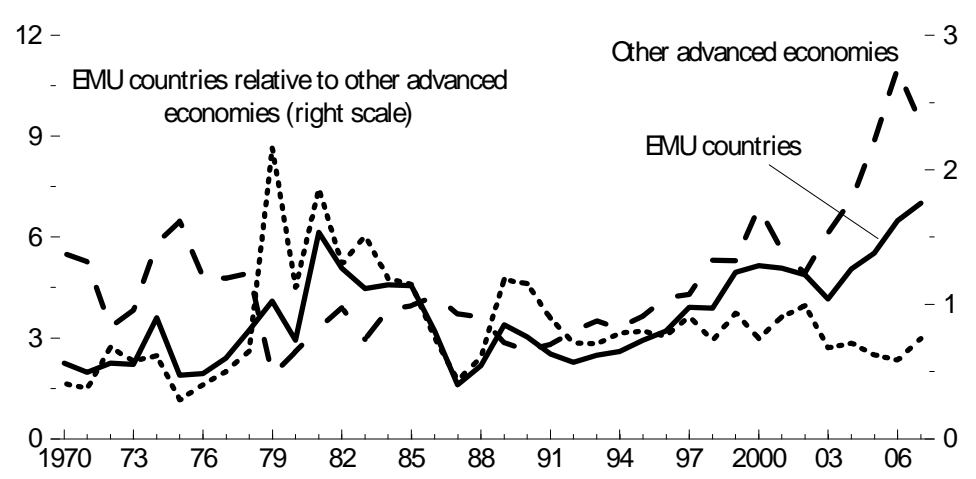

Sources: WEO, 2008, and IMF staff calculations.

1/ Based on current account balances in percent of GDP. Divergences are measured by the standard deviations across EMU countries and across the other advanced countries, respectively.

that the global dispersion of current accounts has been steadily rising and argue that ongoing financial globalization has allowed countries to maintain larger current account imbalances. Overall, this initial peek at the current account data does not reveal a clear association between current account dispersion and exchange rate rigidity.

\section{Country-specific current account shocks and dynamics}

Shocks and dynamics are analyzed using a panel data set for 1970-2007 on current accounts for the 11 EMU and 13 advanced non-EMU countries under review. The main finding is that the size of country-specific current account shocks has dropped for euro-area countries, to a significantly lower level than for the other advanced countries, while also becoming more persistent than in these economies.

The following regression is fitted to the data:

$$
\begin{aligned}
& \operatorname{cad}_{i t}=\sum_{i=1}^{24}\left(d_{1 i}+d_{2 i} D_{92-07}+d_{3 i} D_{99-07}\right)+ \\
& \sum_{j=1}^{2}\left(b_{j}+d_{4 j} D_{R O W}+d_{5 j} D_{92-07}+d_{6 j} D_{92-07} D_{R O W}+d_{7 j} D_{99-07}+d_{8 j} D_{99-07} D_{R O W}\right) c a d_{i(t-j)}+\varepsilon_{i t}
\end{aligned}
$$

where, cad $_{i t}$ is the deviation of the current account balance (expressed in percent of GDP) of country $i$ from the current account balance of the respective sample of countries. For EMU members, the latter is the balance for the euro area; for the other economies, it is the sum of their current account balances divided by the sum of their nominal gross domestic products.

The equation features fixed effects to capture cross-country differences in steady-state current account balances, because the structural determinants of countries' current accounts differ (see Section V). Also, it includes a number of dummies to test for differences in 
current account dynamics over various periods as well as between the euro-area countries on the one hand and the 13 other advanced economies on the other hand. Specifically, intercept and slope coefficients were introduced for the periods 1992-2007 (D92-07), and 1999-2007 ( $\left.D_{99-07}\right)$ : these dummies mark the two major regime shifts, namely, agreement on the objective of a single currency and conditions in 1992 (Maastricht Treaty) and the ultimate adoption of a single currency in 1999. Furthermore, slope coefficients for the group of nonEMU countries $\left(\mathrm{D}_{\mathrm{ROW}}\right)$ test for significant differences in current account behavior between non-EMU and EMU countries.

Starting with the general regression, successive F-tests suggest that at a 5 percent or lower significance level: (i) the country-specific intercepts differ for the periods starting in 1992 and 1999-i.e., estimates for $\mathrm{d}_{2 \mathrm{i}}$ are jointly significant and so are those for $\mathrm{d}_{3 \mathrm{i}}$; (ii) the speed of current account adjustment to shocks falls after 1992 but does not decline further after 1999, i.e., the estimates for $d_{5 j}$ are jointly smaller than zero but those for $d_{7 j}$ are not; (iii) for EMU countries, the speed of adjustment to shocks slowed after 1992 relative to that for the other advanced economies but did not slow further after 1999, i.e., the estimates for $\mathrm{d}_{6 \mathrm{j}}$ are jointly smaller than zero while those for $\mathrm{d}_{8 \mathrm{j}}$ are not. ${ }^{4}$

The next step involves fitting a univariate time series regression separately to the two samples-EMU and non-EMU, as well as for three subperiods: 1972-91, 1992-2007, and 1999-2007. Specifically, the following regression is run:

$$
\operatorname{cad}_{i t}=\sum_{i=1}^{N} d_{i}+\sum_{j=1}^{2} b_{j} \operatorname{cad}_{i(t-j)}+\varepsilon_{i t}
$$

Figure 2. Adjustment to Country-Specific Current Account Shocks ${ }^{1 /}$ (In Years)

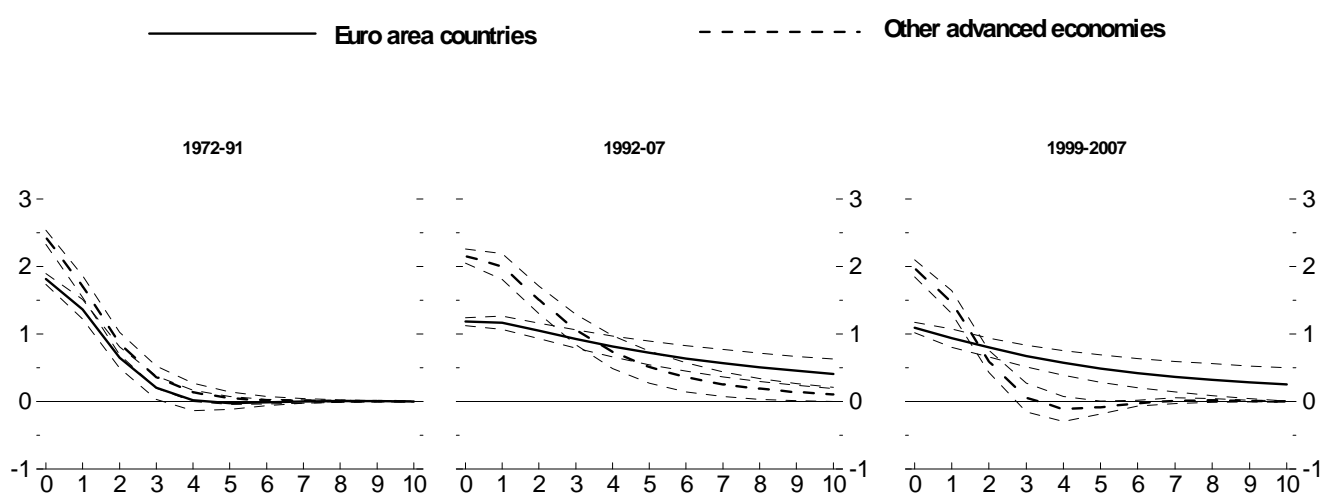

Source: IMF staff calculations.

1/ Country current account balance minus the respective sample current account balance. Impulse response functions with "two standard error" bands are from fitting equation (2) to the data. The shock size is one standard deviation.

${ }^{4}$ The results are available from the authors upon request. 
The left panel of Figure 2 shows that the size of shocks, which measures one standard deviation, and the speed of adjustment were very similar in EMU and non-EMU countries during 1972-91. The other panels show that during 1992-2007 the speed of adjustment slowed noticeably in EMU countries, to a significantly lower level than in the other advanced economies. Interestingly, the size of the shocks fell as well, unlike in the 13 other advanced economies, testifying to the growing integration of EMU members. The panels also show that there has not been much further change in the size of the shocks and speed of adjustment after monetary union.

\section{The Role OF THE Exchange RATE AND OTHER FActors}

This section investigates the role that the exchange rate might have played in changing current account dynamics, starting with a brief analysis of cross-sectional dispersion and then focusing on shocks and dynamics.

\section{Cross-sectional dispersion of exchange rate changes}

The cross-sectional divergence of real effective exchange rate changes has gone down for EMU countries but moved broadly sideways for the other advanced countries (Figure 3). However, the downward move in dispersions for EMU countries was largest in the advent of monetary union, during 1993-99, rather than afterwards, which is partly related to countries having had to meet the Maastricht membership criteria. ${ }^{5}$ While the reduced cross-sectional dispersion in exchange rate changes has coincided with an increased dispersion of current accounts, this says little about causality, considering that current account dispersions (i) have not moved up systematically as exchange rate dispersions have declined; and (ii) have moved up to a

Figure 3. Real Exchange Rate Dispersions (Standard deviation of real effective exchange rate changes)

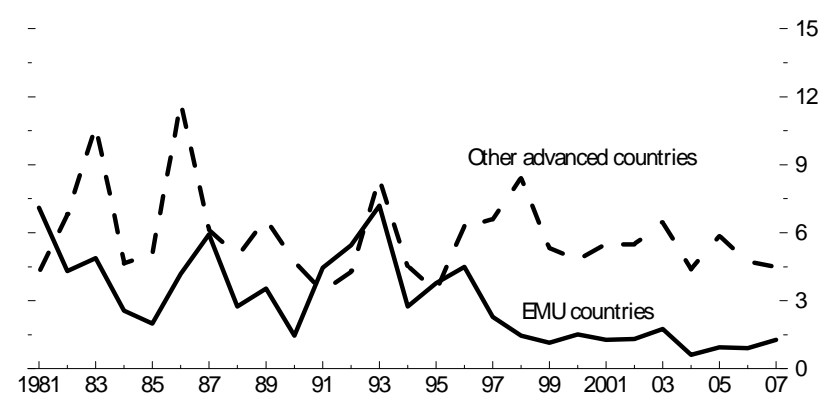

Sources: WEO, 2008, and IMF staff calculations. 1 / Based on percent real effective exchange rate changes. Divergences are measured by the standard deviations across EMU countries and across the other advanced countries, respectively.

\footnotetext{
${ }^{5}$ These included participation in the European Monetary System for at least two years without significant deviations of the exchange rate from centrally-set parities or need for intervention. Specifically, until January 1, 1999, EU countries typically tried to maintain their currencies within certain fluctuation margins of one another, although there were frequent realignments of central currency parities. These amounted to $\pm 2 \frac{1}{4}$ percent (for Italy, \pm 6 percent); following the September 1992 European exchange rate crisis, the margins were widened to \pm 15 percent. The margins were part of various exchange rate systems: the "snake in the tunnel" (1971-73), the "floating snake" (1973-79), and the European Monetary System (1979-99). For further discussion see, for example, Giavazzi and others (1988) and Giavazzi and Giovannini (1989).
} 
larger extent across the other advanced economies, for which dispersions of exchange rate changes have not fallen.

\section{The role of changes in exchange rate dynamics}

An interesting hypothesis to investigate is whether the increase in the persistence of current account shocks observed for EMU members in the post-1992 sample-to above the persistence observed for other advanced countries - may be related to increasingly rigid intra-area exchange rates following the 1992 commitment to move to a single currency. This question can be analyzed by examining the joint behavior of the current account and the real exchange rate. Specifically, if upon conditioning on the real exchange rate, the persistence of current account shocks in the post-1992 sample is as low as has been found for the pre-1992 sample, then the move to more rigid exchange rates and a single currency may help explain the slow post-1992 current account adjustment of EMU countries. If not, then the greater persistence of post-1992 current account shocks more likely is related to other factors.

To test for this, equation (1) is re-estimated by adding as a regressor the deviation of the real effective exchange rate of country $i$ from the average real effective exchange rate of the respective country groups: reerd $_{i t}$. An increase in reerd ${ }_{i t}$ denotes an appreciation of a country's real effective exchange rate relative to the real exchange rate of the country's entire group. For EMU members, this group variable is the real effective exchange rate for the euro area as whole. For the 13 other advanced economies, it is a weighed average of their real effective exchange rates, with the weights determined by the share of each country's exports and imports in total exports and imports of the 13 economies. ${ }^{6}$ Notice that the data for real effective exchange rates are available on a consistent basis only from 1980 onward. The following equation is fitted to the data:

$$
\begin{aligned}
& \operatorname{cad}_{i t}=\sum_{i=1}^{24}\left(d_{1 i}+d_{2 i} D_{92-07}+d_{3 i} D_{99-07}\right)+ \\
& \sum_{j=1}^{2}\left(b_{j}+d_{4 j} D_{R O W}+d_{5 j} D_{92-07}+d_{6 j} D_{92-07} D_{R O W}+d_{7 j} D_{99-07}+d_{8 j} D_{99-07} D_{R O W}\right) \operatorname{cad}_{i(t-j)}+ \\
& \sum_{j=1}^{3}\left(c_{j}+d_{9 j} D_{R O W}+d_{10 j} D_{92-07}+d_{11 j} D_{92-07} D_{R O W}+d_{12 j} D_{99-07}+d_{13 j} D_{99-07} D_{R O W}\right) \text { reerd }_{i(t-j+1)}+\varepsilon_{i t}
\end{aligned}
$$

The key finding is that introducing real exchange rates does not lower the persistence of the current account dynamics (Table 1). In the most general specification, the reerd ${ }_{\text {it }}$ parameter estimates are jointly significant at the 5 percent level. ${ }^{7}$ Nonetheless, all the results from fitting

\footnotetext{
${ }^{6}$ A better measure would be to use a real effective exchange rate for the group of 13 advanced economies, which would be a function of bilateral exchange rates and trade relations only with countries outside this group. However, this is available only for the euro area.

${ }^{7}$ Adding the reerd $_{\text {it }}$ raises the Rbar by 6 percent, from 81.5 percent to 87.5 percent.
} 
equation (1) continue to hold. In particular, current account shocks are smaller and the speed of adjustment within EMU members is significantly slower after 1992 even conditioning on real effective exchange rates.

Table 1. Estimates of Speed of Adjustment of Current Accounts ${ }^{1 / 2 /}$

\begin{tabular}{|c|c|c|c|c|c|c|c|c|}
\hline Sample & \multicolumn{2}{|c|}{$1972-2007$} & \multicolumn{2}{|c|}{$1972-2007$} & \multicolumn{2}{|c|}{$1982-2007$} & \multicolumn{2}{|c|}{$1982-2007$} \\
\hline Degress of Freedom & \multicolumn{2}{|c|}{753} & \multicolumn{2}{|r|}{759} & \multicolumn{2}{|r|}{519} & \multicolumn{2}{|c|}{537} \\
\hline $\mathrm{R}$ Bar * 2 & \multicolumn{2}{|c|}{0.82} & \multicolumn{2}{|r|}{0.82} & \multicolumn{2}{|r|}{0.88} & \multicolumn{2}{|c|}{0.88} \\
\hline \multirow{2}{*}{ Equation } & \multicolumn{2}{|c|}{1} & \multicolumn{2}{|r|}{1} & \multicolumn{2}{|c|}{3} & \multicolumn{2}{|c|}{3} \\
\hline & Coeff & $\begin{array}{l}\text { tandard } \\
\text { Error }\end{array}$ & Coeff & $\begin{array}{l}\text { Standara } \\
\text { Error }\end{array}$ & Co eff & $\begin{array}{l}\text { Standard } \\
\text { Error }\end{array}$ & Coeff & $\begin{array}{l}\text { tandard } \\
\text { Error }\end{array}$ \\
\hline$b_{1}$ & 0.75 & $(0.08) * \star \star$ & 0.72 & $(0.04) * * *$ & 0.72 & $(0.08) * \star \star$ & 0.69 & $(0.05)^{* * *}$ \\
\hline$b_{2}$ & -0.17 & $(0.08) * \star$ & -0.16 & $(0.04) * * *$ & -0.13 & $(0.08)$ & -0.17 & $(0.05) * * *$ \\
\hline$d_{41}$ & -0.04 & $(0.09)$ & & & -0.08 & $(0.11)$ & & \\
\hline$d_{42}$ & 0.02 & $(0.09)$ & & & -0.08 & $(0.10)$ & & \\
\hline$d_{51}$ & 0.14 & $(0.17)$ & 0.14 & $(0.14)$ & 0.15 & $(0.16)$ & 0.15 & $(0.12)$ \\
\hline$d_{52}$ & 0.13 & $(0.17)$ & 0.10 & $(0.14)$ & 0.11 & $(0.15)$ & 0.11 & $(0.12)$ \\
\hline$d_{61}$ & -0.20 & $(0.20)$ & -0.09 & $(0.15)$ & -0.15 & $(0.19)$ & -0.10 & $(0.12)$ \\
\hline$d_{62}$ & -0.29 & $(0.20)$ & -0.26 & (0.16) & -0.21 & $(0.18)$ & -0.27 & $(0.13)$ \\
\hline$d_{71}$ & -0.05 & $(0.16)$ & & & -0.05 & $(0.14)$ & & \\
\hline$d_{72}$ & -0.02 & $(0.14)$ & & & -0.03 & $(0.12)$ & & \\
\hline$d_{81}$ & 0.25 & $(0.19)$ & & & 0.19 & $(0.17)$ & & \\
\hline$d_{82}$ & -0.04 & $(0.17)$ & & & 0.03 & $(0.14)$ & & \\
\hline $\mathrm{c}_{1}$ & & & & & 0.01 & $(0.02)$ & 0.00 & $(0.02)$ \\
\hline $\mathrm{c}_{2}$ & & & & & -0.04 & $(0.03)$ & -0.03 & $(0.02)$ \\
\hline$c_{3}$ & & & & & 0.02 & $(0.02)$ & 0.01 & $(0.02)$ \\
\hline$d_{91}$ & & & & & -0.08 & $(0.03) * *$ & -0.08 & $(0.03) * * *$ \\
\hline$d_{92}$ & & & & & 0.10 & $(0.04) * *$ & 0.06 & $(0.03)$ * \\
\hline$d_{93}$ & & & & & -0.06 & $(0.03)$ * & -0.03 & $(0.02)$ \\
\hline$d_{101}$ & & & & & -0.05 & $(0.04)$ & & \\
\hline$d_{102}$ & & & & & 0.03 & $(0.03)$ & & \\
\hline$d_{103}$ & & & & & -0.01 & $(0.03)$ & & \\
\hline$d_{111}$ & & & & & -0.02 & $(0.05)$ & & \\
\hline$d_{112}$ & & & & & -0.03 & $(0.05)$ & & \\
\hline$d_{113}$ & & & & & 0.01 & $(0.04)$ & & \\
\hline$d_{121}$ & & & & & 0.04 & $(0.06)$ & & \\
\hline$d_{122}$ & & & & & 0.01 & $(0.05)$ & & \\
\hline$d_{123}$ & & & & & 0.02 & $(0.04)$ & & \\
\hline$d_{131}$ & & & & & 0.04 & $(0.07)$ & & \\
\hline$d_{132}$ & & & & & -0.12 & $(0.07)$ * & & \\
\hline$d_{133}$ & & & & & 0.10 & $(0.06)$ & & \\
\hline
\end{tabular}

Source: IMF staff estimates. Estimates are from fitting equations (1) and (3) to the data. 1/ Significance levels: *** 1 percent level; ** 5 percent; * 10 percent level.

$2 /$ Intercept coefficients are available from the authors on request. 
The final step consists of fitting the following bivariate VAR—-featuring cad $_{i t}$ and reerd ${ }_{i t}$ - to the data:

$$
\begin{aligned}
& \operatorname{cad}_{i t}=\sum_{i=1}^{24} a_{i}+\sum_{j=1}^{2} b_{j} \text { cad }_{i t-j}+\sum_{j=1}^{2} c_{j} \text { reerd }_{i t-j}+\varepsilon_{i t} \\
& \text { reerd }_{i t}=\sum_{i=1}^{24} f_{i}+\sum_{j=1}^{2} d_{j} \text { reerd }_{i t-j}+\sum_{j=1}^{2} h_{j} \text { cad }_{i t-j}+\eta_{i t}
\end{aligned}
$$

This is done for several samples: 1982-1991 (reerd it $_{\text {data }}$ are not available for before 1980); 1992-2007; and 1999-2007. Figures 4a and 4b show the impulse responses, with the ordering of variables assuming that reerd ${ }_{i t}$ is exogenous to cad $_{i t}$. The results discussed here also hold for this reverse ordering, with one exception discussed below.

The first step is to scrutinize the responses of the current account to current account shocks and of real exchange rates to real exchange rate shocks. The current account impulse responses confirm the key finding of the univariate current account analysis (Figure 4a). Specifically, current account shocks in EMU countries are only about 60 percent of the size of shocks in the other advanced economies. The drop in shock size between the pre- and post-1992 sample observed in the univariate cad $_{i t}$ regressions is located in the 1980s (see Appendix); since then, shock size has remained broadly unchanged. Second, current account shocks are as persistent in EMU countries as in the other economies in 1982-91, but are more persistent in the later samples. Real exchange rate impulse responses yield several interesting results (Figure 4b). In particular, the size of the real exchange rate shocks is about the same in EMU countries as that experienced by the other advanced economies in 1982-91 but then falls, to about 60 percent of the size of that in the other economies in 1999-2007, with the break situated in 1992 rather than 1999. Furthermore, the shocks have lately become more persistent in the other countries but, contrary to fears, not in the EMU countries.

The second step is to examine how the current account responds to real exchange rate shocks. Such shocks can be associated with changes in interest rates and risk premia but may also reflect other factors, such as wage setting. Notice that an appreciation of the real exchange rate (positive shock) generally triggers a current account deterioration. However, the response for the EMU countries is much smaller than that for the other advanced countries. Impulse responses from rolling regressions with 10-year samples suggest that EMU countries feature a strong response only around the exchange rate realignments of $1993 .{ }^{8}$ Also, for the

\footnotetext{
${ }^{8}$ These results are available from the authors upon request.
} 
post-1999 period it becomes positive, although it is wholly insignificant. By contrast, in the other advanced economies the current account responses become more negative after $1992 .{ }^{9}$

Figure 4a: EMU and Other Countries: Impulse Responses of the Current Account (In response to a one standard deviation shock)

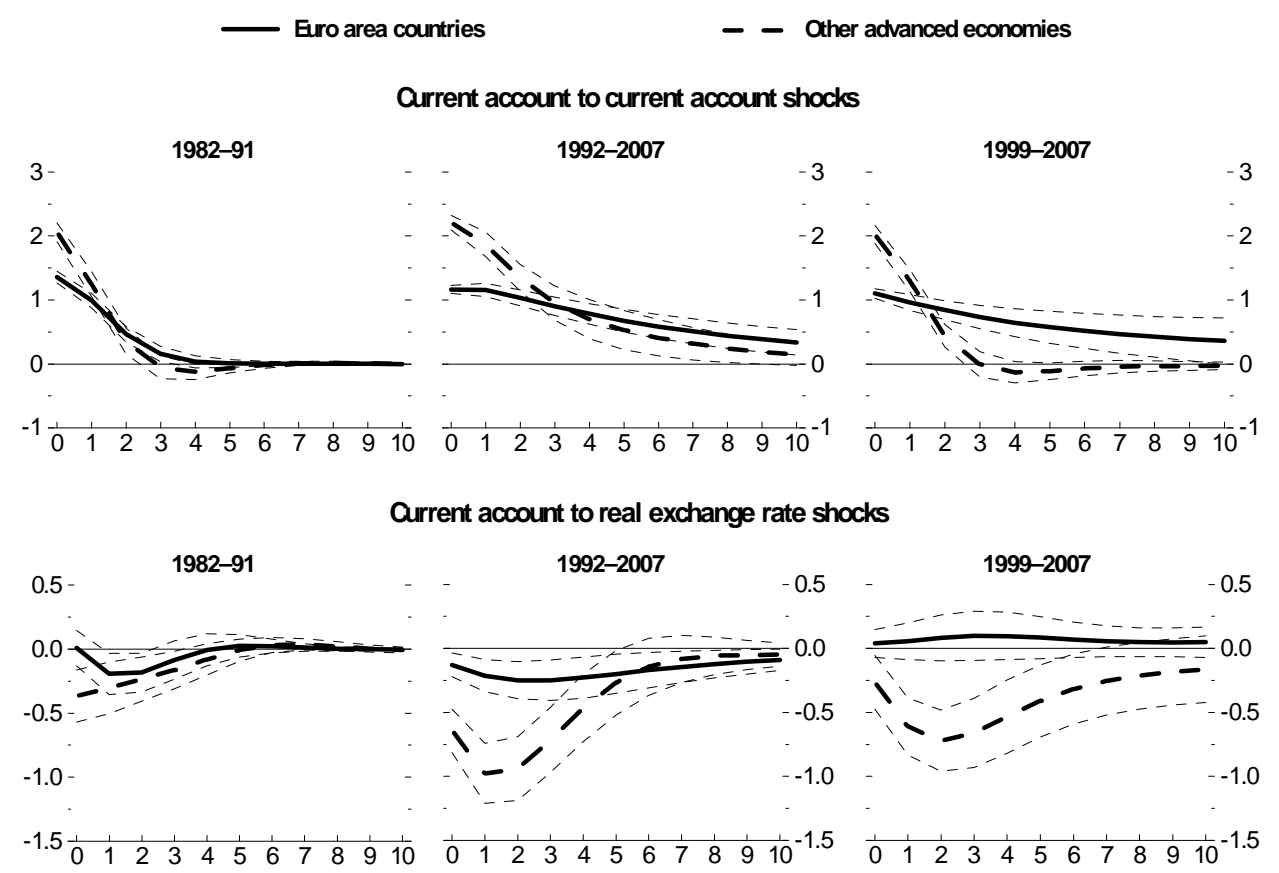

Source: IMF staff calculations. The figures show the respective impulse responses and two standard error bands obtained from fitting the system of equations (4) to the data.

The final step investigates the response of the exchange rate to current account shocks. Underlying these shocks could be changes to the terms of trade, for example. For EMU countries, country-specific current account improvements are generally not associated with country-specific appreciations of the real exchange rate. For the other advanced economies they are, although this is the only finding that is not robust to the ordering of the variables in the impulse responses: on the assumption that $\operatorname{cad}_{i t}$ is the more exogenous variable, the findings resemble those for EMU countries. These mixed findings are in line with a large body of evidence in the literature on the limited extent to which macroeconomic fundamentals can explain exchange rate movements at short horizons.

\footnotetext{
${ }^{9}$ However, the error bands and, more importantly, the results from fitting equation (3) suggest that the differences between EMU and the other countries need to be treated cautiously. Successive F-tests on equation (3) suggest that the estimates for $\mathrm{d}_{10 \mathrm{j}}, \mathrm{d}_{11 \mathrm{j}}, \mathrm{d}_{12 \mathrm{j}}$, and $\mathrm{d}_{13 \mathrm{j}}$ are jointly insignificant at conventional levels. The estimate for $\mathrm{d}_{9 \mathrm{j}}$, however, is significant at the 5 percent level and negative, suggesting that over the full sample the current account declines more in response to an appreciation of the real exchange rate in the other advanced economies than in EMU countries.
} 
Figure 4b: EMU and Other Countries: Impulse Responses of the Real Exchange Rate (In response to a one standard deviation shock)

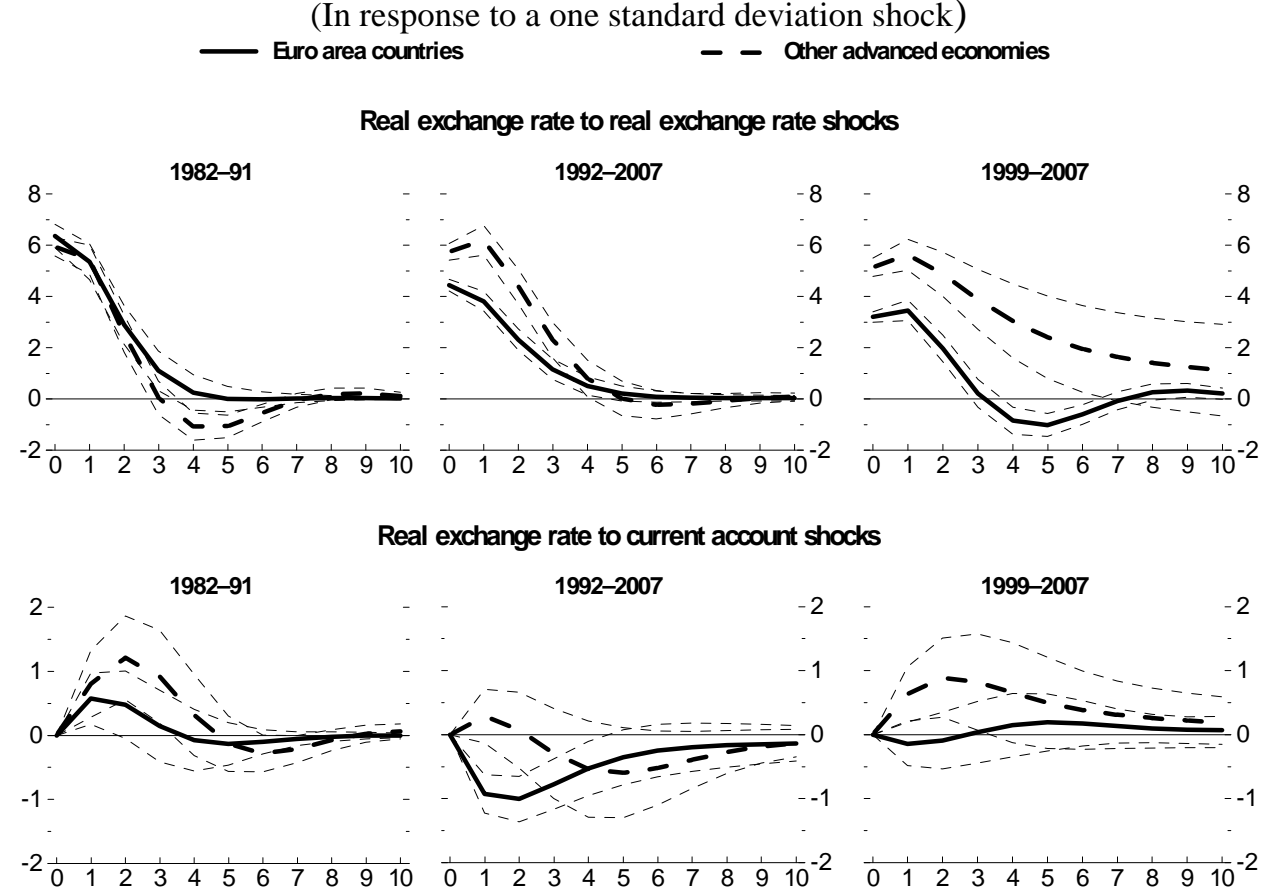

Source: IMF staff calculations. The figures show the respective impulse responses and two standard error bands obtained from fitting the system of equations (4) to the data.

\section{Cross-sectional evidence on current account and real exchange rate persistence}

The evidence thus far suggests that current account shocks have become more persistent in the euro area but that this is not obviously related to changes in real exchange rate dynamics. This subsection takes another stab at the persistence issue, gauging current account and real exchange rate persistence for each country and then examining whether the two are cross sectionally related. To do so, the following regressions are fitted to the data:

$$
\begin{aligned}
& \operatorname{cad}_{i t}=a_{11}+a_{12 i} \text { cad }_{i t-1}+\varepsilon_{1 i t} \\
& \text { reerd }_{i t}=a_{21}+a_{22 i} \text { reerd }_{i t-1}+\varepsilon_{2 i t} \\
& a_{12 i}=a_{31}+b_{1} a_{22 i}+\varepsilon_{3 i} \\
& a_{12 i}=a_{31}+a_{41} D_{\text {euro }}+\left(b_{1}+d_{1} D_{\text {euro }}\right) a_{22 i}+\varepsilon_{4 i} \\
& \left(a_{12 i}^{92-07}-a_{12 i}{ }^{81-91}\right)=a_{31}+a_{41} D_{\text {euro }}+\left(b_{1}+d_{1} D_{\text {euro }}\right)\left(a_{22 i}{ }^{92-07}-a_{22 i}{ }^{81-91}\right)+\varepsilon_{5 i}
\end{aligned}
$$

The first two equations (5) regress for each country the country-specific current account cad $_{\text {it }}$ or real exchange rate reerd ${ }_{i t}$ on their respective lags. The objective is to compute the autoregressive coefficients $\mathrm{a}_{12 \mathrm{i}}$ and $\mathrm{a}_{22 \mathrm{i}}$, which are simple indicators of persistence of the current account and real exchange rate, respectively. Equation (6) then regresses the indicator 
of current account persistence for each country $\left(\mathrm{a}_{12 \mathrm{i}}\right)$ on that of real exchange rate persistence $\left(\mathrm{a}_{22 \mathrm{i}}\right)$. Equation (7) does the same but allows for different intercept and slope coefficients for the euro-area countries $\left(\mathrm{a}_{41}\right.$ and $\left.\mathrm{d}_{1}\right)$, with $\mathrm{D}_{\text {euro }}$ denoting a dummy variable for euro-area countries. Equation (8) tests for an association between the change in current account persistence in 1992-2007 relative to 1981-1991 on the one hand, and the change in real exchange rate persistence on the other hand.

The results, shown in Table 2 and Figure 5 below, suggest that there is no significant association between current account and real exchange rate persistence. This holds for both the full cross section as well as for the sample of the 11 EMU countries. In particular, the estimates for $b_{1}$ and $d_{1}$ are generally small, except for the sample of EMU countries for the period 1992-2007. However, for that sample and all other samples they are wholly insignificant at conventional levels. Moreover, while the estimate for $d_{1}$ is positive and large for equation (7) for the 1992-2007 sample, it is negative and large for equation (8).

Table 2. Current Account and Real Exchange Rate Persistence ${ }^{1 /}$

\begin{tabular}{|c|c|c|c|c|c|c|c|c|c|c|}
\hline Sample & \multicolumn{2}{|c|}{ 1981-1991 } & \multicolumn{2}{|c|}{ 1981-1991 } & \multicolumn{2}{|c|}{ 1992-2007 } & \multicolumn{2}{|c|}{$1992-2007$} & \multicolumn{2}{|c|}{ 1992-2007/1981-1991 } \\
\hline Degrees of Freedom & \multicolumn{2}{|c|}{22} & \multicolumn{2}{|c|}{20} & \multicolumn{2}{|c|}{22} & \multicolumn{2}{|c|}{20} & \multicolumn{2}{|c|}{20} \\
\hline $\mathrm{R}$ Bar * 2 & \multicolumn{2}{|c|}{-0.04} & \multicolumn{2}{|c|}{-0.15} & \multicolumn{2}{|c|}{-0.05} & \multicolumn{2}{|c|}{0.09} & \multicolumn{2}{|c|}{0.03} \\
\hline \multirow[t]{2}{*}{ Equation } & \multicolumn{2}{|c|}{6} & \multicolumn{2}{|c|}{7} & \multicolumn{2}{|c|}{6} & \multicolumn{2}{|c|}{7} & \multicolumn{2}{|c|}{8} \\
\hline & Coeff & $\begin{array}{l}\text { tandard } \\
\text { Error }\end{array}$ & Coeff & $\begin{array}{l}\text { Standard } \\
\text { Error }\end{array}$ & Coeff & $\begin{array}{l}\text { Standard } \\
\text { Error }\end{array}$ & Coeff & $\begin{array}{l}\text { Standard } \\
\text { Error } \\
\end{array}$ & Coeff & $\begin{array}{l}\text { Standard } \\
\text { Error }\end{array}$ \\
\hline$b_{1}$ & -0.04 & $(0.30)$ & -0.13 & $(0.50)$ & -0.23 & $(0.38)$ & -0.33 & $(0.41)$ & 0.61 & $(0.99)$ \\
\hline$d_{1}$ & & & 0.10 & $(0.70)$ & & & 0.95 & $(0.85)$ & -0.96 & (1.07) \\
\hline
\end{tabular}

Source: IMF staff estimates. Estimates are from fitting equations (6), (7), and (8) to the data. 1/ Significance levels: *** 1 percent level; ** 5 percent; * 10 percent level.

Figure 5. EMU and Other Countries: Correlation Between Current Account and Real Exchange Rate Persistence ${ }^{1 /}$
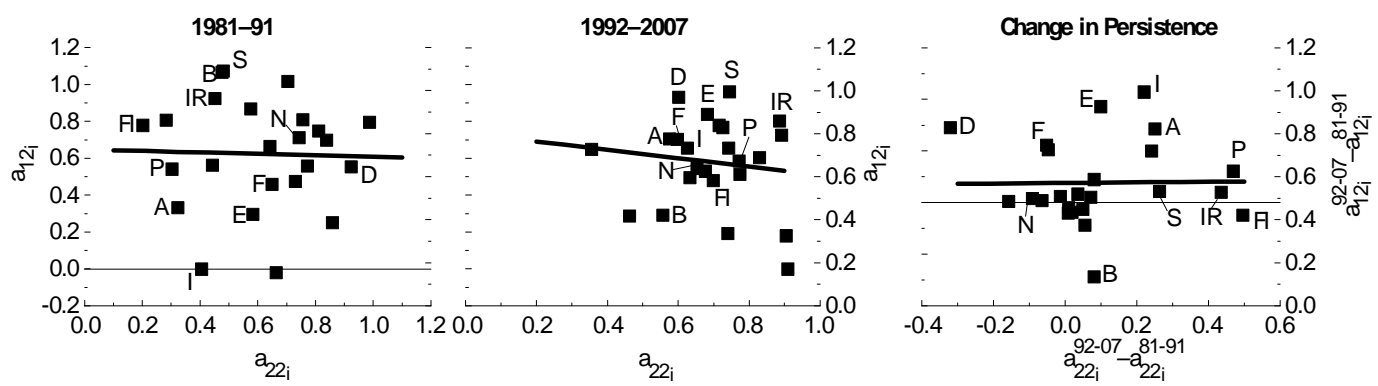

Source: IMF staff estimates.

$1 / \mathrm{a}_{12 \mathrm{i}}$ and $\mathrm{a}_{22 \mathrm{i}}$, respectively, denote the persistence parameter estimates obtained by fitting the two equations (5) to the data. Euro-area countries are identified as follows: Austria (A), Belgium (B), Germany (D), Finland (FI), France (F), Greece (G), Ireland (IR), Italy (I), Netherlands (N), Portugal $(\mathrm{P})$, Spain $(\mathrm{S})$. 


\section{The role of fundamental determinants of current accounts}

The last question to be examined is to what extent current account developments among EMU countries are a reflection of fundamental versus disequilibrium forces and how these have evolved over time. Thus far, the paper compared developments in EMU countries with those in other advanced economies as well as developments pre-1992/99 with those post1992/99. This section compares EMU countries' current accounts with estimates of current accounts as determined by "fundamentals." The main finding is that the more recent increase in cross-sectional current account dispersion for EMU countries can largely be accounted for by fundamental variables. While there are deviations from "fundamentals" in various countries, these are not far out of line with historical developments.

To investigate this issue, a model of fundamental current account balances based closely on the IMF CGER methodology (Lee and others, 2008) is used. The first step models the current account as a function of various fundamental variables:

$c a_{i t}=a+b_{1} g_{i t}+b_{2} y r_{i t}+b_{3}$ pop $_{i t}+b_{4} n f a_{i t}+b_{5} f b_{i t}+b_{6} d e p_{i t}+b_{7} o i l_{i t}+\varepsilon_{i t}$

where, $c a_{i t}$ is the current account balance in percent of GDP of country $i, g_{i t}$ is real GDP growth, $y r_{i t}$ is per capita income relative to Germany, $p o p_{i t}$ is population growth, $n f a_{i t}$ is net foreign assets to GDP ratio, measured before the period of reference for the current account balance so as to avoid capturing a reverse link from the current account balance to NFA, $f b_{i t}$ is fiscal balance in percent of GDP, $d e p_{i t}$ is old age dependency ratio, and $o i l_{i t}$ is oil balance in percent of GDP. Per capita income relative to Germany is used to control for the relative stage of economic development. ${ }^{10}$ The above equation is estimated using annual data over the period 1970-2007.

Notice that the specification of equation (9) is guided by both economic theory and empirical evidence. Specifically, GDP growth, as shown in Obstfeld and Rogoff (1996), captures the external borrowing needs for economies at an early stages of economic development with a greater need for investment. Relatedly, the relative per-capita income measures the relative stage of economic development, with the current account balance increasing with relative income. Fiscal balance captures the effect of national savings, as a higher government budget balance raises national saving and thereby increases the current account balance (e.g., Chinn, 2005). Demographics also proxies national savings, as a higher share of the economically inactive dependent population reduces national saving and decreases the

\footnotetext{
${ }^{10}$ Ca'Zorzi and Rubaszek (2008) explain current account dispersions for EMU members using a calibrated intertemporal model with consumption smoothing and capital accumulation. Their model explains most of the dispersions in the current account and saving ratios but does not capture well differences in the investment ratio. They conclude that consumption smoothing, based on expectations of economic convergence, is driving the current accounts of the euro area countries over medium-term horizons, while capital accumulation appears to play a less pronounced role.
} 
current account balance (e.g., Higgins, 1998). Net Foreign Assets (NFA) can have either positive or negative effect the current account balance-it can deteriorate, as countries with relatively high NFA can afford to have trade deficits for extended periods, or it can improve, as economies with high NFA experience higher net foreign income flows. According to standard open economy macroeconomic models, the second effect should dominate.

The regression results reveal that all the coefficients enter with the expected signs and almost all are significant at conventional levels (Table 3). High real GDP or population growth and a high old-age dependency ratio lower the current account. A high level of per capita GDP relative to Germany or a high fiscal balance, net foreign assets, or oil trade balance, increase a country's current account.

Table 3. Estimates of the Current Account Equation

\begin{tabular}{|c|c|c|c|}
\hline Variable & Coefficient & \multicolumn{2}{|c|}{ Std. Error 1/ } \\
\hline Constant & 0.02 & $(0.02)$ & \\
\hline Real GDP growth & -0.20 & $(0.11)$ & * \\
\hline Per capita income, relative to Germany & 0.06 & $(0.01)$ & $* * *$ \\
\hline Fiscal balance, in percent of GDP & 0.18 & $(0.06)$ & $* * *$ \\
\hline Old dependency ratio & -0.17 & $(0.07)$ & $* *$ \\
\hline Net foreign assets, in percent of GDP & 0.04 & $(0.01)$ & $* * *$ \\
\hline Oil balance, in percent of GDP & 0.54 & $(0.12)$ & $* * *$ \\
\hline Population growth & -2.79 & $(0.47)$ & $* * *$ \\
\hline Observations & 254 & & \\
\hline Cross section & 11 & & \\
\hline Sample period & $1975-2007$ & & \\
\hline Adjusted R-squared & 0.52 & & \\
\hline
\end{tabular}

Source: IMF staff estimates. Estimates are from fitting equation (9) to the data. 1/ Significance levels: *** 1 percent level; ** 5 percent; * 10 percent level.

The next step computes estimates of "fundamental" current accounts for each EMU-member country, by substituting the trend (10-year trailing moving average) of the right-hand-side variables into regression equation (9). The argument is that the 10-year moving averages capture the sustained, structural change in the explanatory variables. These sustained, structural changes are assumed to determine the fundamental or "equilibrium” current account.

As can be seen (Table 4), current account balances vary from deficits exceeding 10 percent of GDP to surpluses above 5 percent of GDP in 2007. The variation across estimates of fundamental current account balances is lower than that for actual current account balances, stretching from deficits close to 6 percent of GDP to surpluses of over 2 percent of GDP. 
Table 4. EMU Countries: Current Account Dispersions and NFA

\begin{tabular}{|c|c|c|c|}
\hline & $\begin{array}{c}\text { Current account } \\
\text { balance 1/ }\end{array}$ & $\begin{array}{c}\begin{array}{c}\text { Estimated } \\
\text { fundamental } \\
\text { current ac count }\end{array} \\
2007 \\
\end{array}$ & NFA position \\
\hline Austria & 2.7 & 1.1 & -22 \\
\hline Belgium & 3.2 & 2.5 & 34 \\
\hline Finland & 4.6 & -0.3 & -28 \\
\hline France & -1.3 & 0.6 & 5 \\
\hline Germany & 5.6 & 2.5 & 28 \\
\hline Greece & -13.9 & -4.4 & -100 \\
\hline Ireland & -4.5 & 1.1 & -1 \\
\hline Italy & -2.2 & -0.1 & -6 \\
\hline Netherlands & 6.6 & 2.2 & 0 \\
\hline Portugal & -9.4 & -5.8 & -80 \\
\hline Spain & -10.1 & -5.7 & -74 \\
\hline
\end{tabular}

Sources: IFS and IMF staff estimates.

1/ Data are based on the April 2008 World Economic Outlook.

Figure 6 shows the cross-sectional standard deviation of fundamental current account balances and of the difference between actual and fundamental current account balances. It does so both in unweighted and PPP-weighted terms. This reveals that the standard deviations of equilibrium current accounts have risen since the late 1990s, suggesting that the widening of current account dispersions during this period (see Figure 1) has a fundamental component. The standard deviation of differences between actual and fundamental current account, which measures each countries disequilibrium component of the current account balance, reached a peak in 2007. However, this peak is not far out of line with previous peaks; it follows on a trough reached in 2003; and, to the extent that there is a trend increase in divergences from fundamentals, it is very small and not obviously related to greater exchange rate rigidity, including monetary union.

Figure 6. EMU Countries: Fundamental Current Account Dispersions

(Standard deviations)
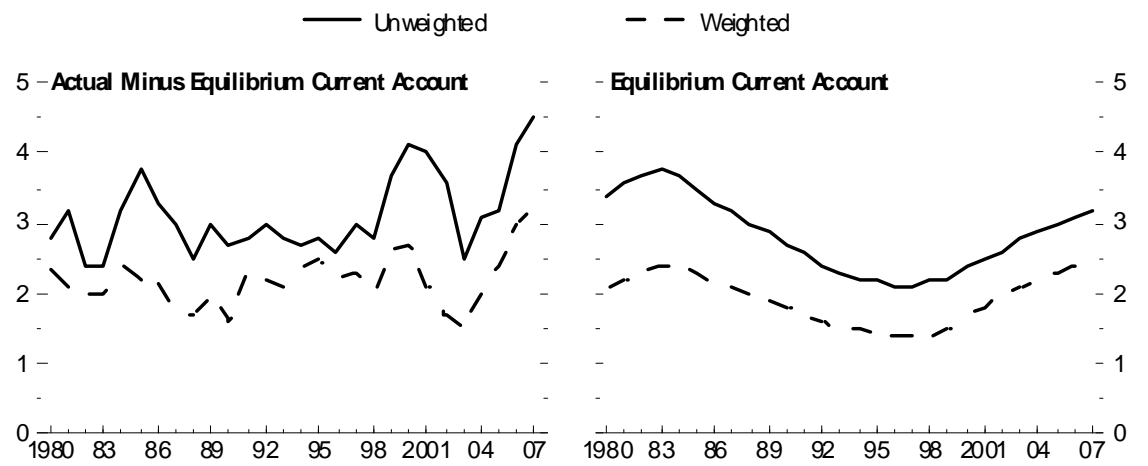

Sources: WEO, 2008, and IMF staff calculations.

1/ Based on current account balances in percent of GDP. Divergences are measured by the standard deviation of the difference between actual and fundamental current accounts as determined with the help of equation (9); and by the standard deviation of fundamental current accounts. 
Figure 7 shows the evolution of the cross sectional variances of the determinants of fundamental current accounts. As can be seen, the cross-sectional variance of many fundamental determinants of current accounts has been rising since the late 1990s, notably for population growth, old-age dependency ratios, and net foreign assets. The latter variable is also the only one that shows a structural increase since 1980, consistent with a view that the growing cross-country dispersion current accounts may be related to the integration of capital markets (e.g., Blanchard and Giavazzi, 2002, and Chang and others, 2008). Real GDP growth fiscal, and oil balances are the only variables featuring trend decreases in dispersion until very lately, suggesting convergence of fiscal policies and oil consumption. ${ }^{11}$

Figure 7. EMU Countries: Dispersions of Determinants of Current Accounts (Cross-sectional standard deviations, 100=average over 1980-2007)

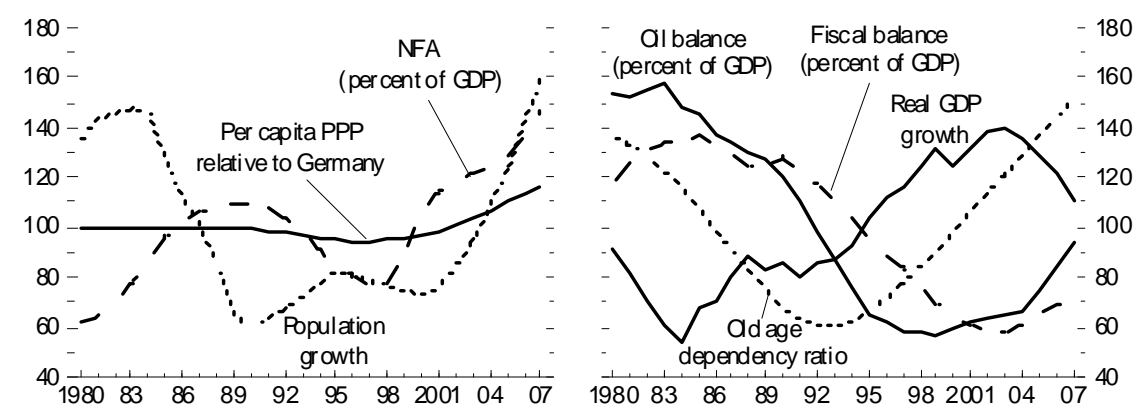

Source: IMF staff estimates.

\section{CONCLUSION}

Current account divergences in EMU countries have widened and this is a trend that dates back to the early 1990s, i.e., to well before the onset of currency union. Such a trend can also be observed for a broad sample of advanced economies outside the euro area. Relative to this sample, divergences across EMU countries have not grown. Furthermore, while there are currently differences between EMU countries' current accounts and estimates for fundamental current accounts, these differences are not unusual by historical standards.

\footnotetext{
${ }^{11}$ This interpretation is in line with findings in the literature on the European Monetary System (EMS) and EMU. For example, Mastropasqua and others (1988) argue that the experience of widening inflation dispersions and ERM strains in response to the second oil price shock in the early 1980s were instrumental in strengthening the consensus for effective adjustment policies. Thygesen (1988) explains that the then EMS framework “was used emphatically to reinforce domestic stabilization...An EMS realignment...helped to trigger major efforts of fiscal tightening in Belgium, Denmark, and France in 1982-82...and prompted the Italian authorities to modify the high degree of monetary financing of the public deficit in the early 1980s and their wage indexation system in 1984. By contrast, during the period of the "snake in the tunnel” (1971-73) and "floating snake" (19731979) — other pegged exchange rate mechanisms_-many countries’ policies were inconsistent with staying “in the system.”
} 
What has changed, however, is the current account dynamics in EMU countries. Specifically, the size of current account shocks has fallen but their persistence has risen. These changes occurred before the onset of currency union in 1999. The current account dynamics in other advanced economies have remained broadly unchanged. As a result, both the size of shocks and the speed of adjustment are now significantly lower in EMU countries than in a sample of 13 other advanced countries.

The findings for the current accounts are robust to conditioning on real effective exchange rates. They suggest that over time the size of shocks to real exchange rates has dropped for EMU countries and that these shocks are now much smaller than for the other advanced countries. Also, they have become less persistent in EMU countries but more persistent in the other economies. Importantly, while current accounts and real exchange rates of the other advanced countries display the responses to shocks that standard models would predict, this is less so for EMU countries. For EMU countries, impulse responses suggest that the relation between current accounts and real exchange rates has gradually weakened. Consistent with these findings, gauging current account and real exchange rate persistence for each country and then examining whether the two are cross sectionally related reveals no significant association.

Overall, the analysis of pre- and post-1992/99 intra euro-area current account and exchange rate developments as well as comparisons of developments in euro-area countries and other advanced economies suggest that there is no straightforward relation between current account dispersions and dynamics on the one hand and exchange rate rigidity on the other. Current account dispersions and dynamics can be driven by many other factors. Some have been discussed here, such as income and demographic dynamics as well as fiscal policies, but there are also others. A careful examination of these factors and their relations with current account and real exchange rate dynamics is left to future work that considers a broader array of variables and better identifies shocks to reach more specific conclusions. Lastly, while an association between changes in EMU current account behavior and exchange rate rigidity is difficult to establish, this does not mean that the unwinding of today's intra-area imbalances will come without costs to economic growth. ${ }^{12}$

\footnotetext{
${ }^{12}$ The large and sustained current account imbalances in the euro area have led to a rapid divergence of countries net foreign asset positions, with some having accumulated a large debt over the past decade. For a succinct discussion of the policy challenges raised by this see Ahearne and Pisani-Ferry (2006) and Blanchard (2006).
} 


\section{Appendix}

This Appendix investigates the location of the break in current account dynamics. Since the evidence for the current account points to breaks in shock size during the 1980s and in persistence during the 1990s, rolling regressions can be used to examine these breaks with more precision. Specifically, the following regression is run for EMU countries:

$$
\operatorname{cad}_{i t}=\sum_{i=1}^{11}\left(d_{1 i}+d_{2 i} D_{x-07}\right)+\sum_{j=1}^{2} b_{j}\left(1+d_{5 j} D_{x-07}\right) \operatorname{cad}_{i t-j}+\varepsilon_{i t} \text {, }
$$

where $x=1973-1999$, i.e., a regression is run with intercept and slope dummies for each year separately. Figure 8 shows the sum of the autoregressive (AR) $\operatorname{cad}_{t-j}$ coefficients and the FStatistic for a structural break for each year during 1973-1999.

Figure 8: EMU Countries: Testing for Structural Breaks

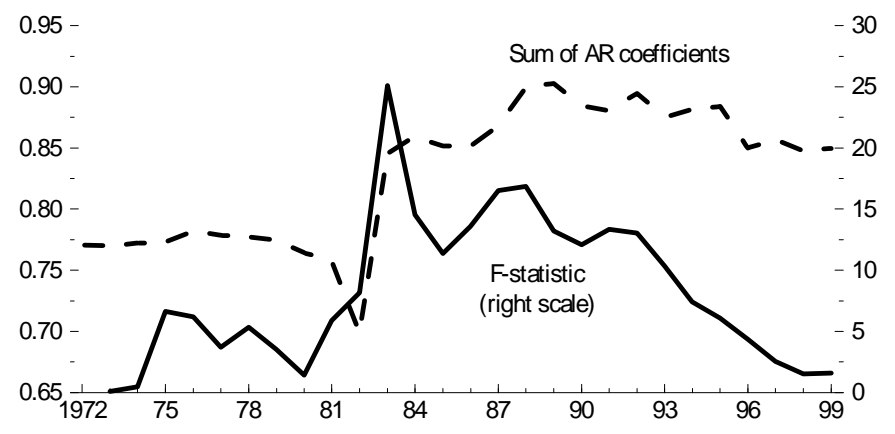

Notice that a break emerges first in the early 1980s and that the sum of the AR coefficients peaks around 1990. Together with the other evidence, this suggests that the adoption of a single currency per se is likely to be only one among several factors explaining the changes in country-specific current account dynamics for EMU countries. 


\section{REFERENCES}

Ahearne, Alan and Jean Pisani-Ferry, 2006, The Euro: Only for the Agile, Bruegel Policy Brief 2006/01.

Altissimo, Fillippo, Michael Ehrmann and Frank Smets, 2005, "Inflation persistence and Price-Setting Behaviour in the Euro Area-A Summary of the IPN Evidence,” ECB Occasional Paper No. 46.

Angeloni, Ignazio and Michael Ehrmann, 2004, “Euro Area Inflation Differentials,” ECB Working Paper No. 388.

Blanchard, Oliver, 2006, “Adjustment within the Euro. The Difficult Case of Portugal,” mimeo.

Blanchard, Olivier and Francesco Giavazzi, 2002, “Current Account Deficits in the Euro Area. The End of the Feldstein Horioka Puzzle?,” MIT Economics Department Working Paper 03-05.

Ca’Zorzi, Michele and Michał Rubaszek, 2008, “On the Empirical Evidence of the Intertemporal Current Account Model for the Euro Area Countries,” ECB Working Paper No. 895.

Chang, Yongsung, Sun-Bin Kim, and Jaewoo Lee, 2009, “Accounting for Global Dispersion of Current Accounts,” mimeo, International Monetary Fund.

Chinn, Menzie, 2005, “Getting Serious About the Twin Deficits,” Council Special Report 10, Council On Foreign Relations.

Chinn, Menzie and Shang-Jin Wei, 2008, “A Faith-based Initiative: Do We Really Know that a Flexible Exchange Rate Regime Facilitates Current Account Adjustment?,” NBER Working Paper No. 14420.

Eickmeier, Sandra, 2006, “Comovements and Heterogeneity in the Euro Area Analyzed in a Non-stationary Dynamic Factor Model,” Deutsche Bundesbank Discussion Paper No. 31.

European Commission, 2006, “Adjustment Dynamics in the Euro Area: Experiences and Challenges,” EC EU Economy Review 2006.

European Central Bank, 2008, $10^{\text {th }}$ Anniversary of the ECB, Special Monthly Bulletin, May.

Faruqee, Hamid, and Jaewoo Lee, 2008, “Global Dispersion of Current Accounts: Is the Universe Expanding?,” forthcoming in IMF Staff Papers. 
Feldstein, Martin, 1997, “The Political Economy of the European Economic and Monetary Union: Political Sources of an Economic Liability,” Journal of Economic Perspectives, Vol. 11, No. 4, Fall 1997, pp. 23-42.

Friedman, Milton, 1953, “The Case for Flexible Exchange Rates,” in M. Friedman, Essays in Positive Economics (Chicago: The University of Chicago Press), pp. 157-203.

Giannone, Domenico, and Lucrezia Reichlin, 2006, "Trends and Cycles in the Euro Area: How Much Heterogeneity and Should we Worry about It?” ECB Working Paper No. 595.

Giavazzi, Francesco and Alberto Giovannini, 1989, Limiting Exchange Rate Flexibility: The European Monetary System, MIT Press Cambridge (MA).

Giavazzi, Francesco, Stefano Micossi, and Marcus Miller (eds), 1988, The European Monetary System, Cambridge University Press.

Ghosh, Atish R., Marco Terrones, and Jeromin Zettelmeyer, 2008, "Exchange Rate Regimes and External Adjustment: New Answers to an Old Debate?” unpublished manuscript.

Higgins, Matthew, 1998, "Demography, National Savings, and International Capital Flows,” International Economic Review, Vol. 39 (2), pp. 343-69.

International Monetary Fund (IMF), 2008, “Country and Regional Perspectives,” World Economic Outlook, World Economic and Financial Surveys (Washington, October).

Ito, Hiro and Menzie Chinn, 2008, “A New Measure of Financial Openness,” Journal of Comparative Policy Analysis, Vol.10 (3) pp. 309-322.

Lane, Philip R. and Milesi-Ferretti, Gian Maria, 2007, “The external wealth of nations mark II: Revised and extended estimates of foreign assets and liabilities, 1970-2004," Journal of International Economics, Vol. 73 (2), pp. 223-250.

Lee, Jaewoo, Gian Maria Milesi-Ferretti, Jonathan David Ostry, Alessandro Prati, and Luca Antonio Ricci, 2008, “Exchange Rate Assessments: CGER Methodologies,” IMF Occasional Paper No. 261.

Mastropasqua, Cristina, Stefano Micossi, and Roberto Rinaldi, 1988, "Interventions, Sterilisation, and Monetary Policy in the European Monetary System, 1979-87,” in Giavazzi et. al (eds), The European Monetary System, Cambridge University Press.

Obstfeld, Maurice and Kenneth Rogoff, 1996, "Foundations of International Macroeconomics,” MIT Press, Cambridge, MA.

Pisani-Ferry, Jean, Philippe Aghion, Marek Belka, Jürgen von Hagen, Lars Keikensten, and André Sapir, 2008, “Coming of Age: Report on the Euro Area,” Bruegel Blueprint No. 4. 
Schmitz, Birgit and Jürgen von Hagen, 2009, “Current Account Imbalances and Financial Integration in the Euro Area,” CEPR Discussion Paper No. 7262.

Stavrev, Emil, 2007, “Growth and Inflation Dispersions in EMU: Reasons, the Role of Adjustment Channels, and Policy Implications,” IMF Working Paper No. 07/167.

Thygesen, Niels, 1988, “Introduction,” in Giavazzi et. al (eds), The European Monetary System, Cambridge University Press.

Wyplosz, Charles, 1997, “EMU: Why and How it Might Happen,” Journal of Economic Perspectives, Vol. 11, No. 4, Fall 1997, pp. 3-22. 